\title{
The use of pediatric logistic organ dysfunction (PELOD) scoring system to determine the prognosis of patients in pediatric intensive care units
}

\author{
Dewi Metta, Dedi Soebardja, Dadang Hudaya S
}

\begin{abstract}
Background Prediction of outcome of patients admitted to pediatric intensive care unit (PICU) requires an objective tool for measurement. It is important to provide information for the patient's family and to explain the objectives of intensive care.

Objective To evaluate whether the Pediatric Logistic Organ Dysfunction (PELOD) scoring system can be used to determine the prognosis of patients treated in PICU.

Methods A longitudinal-observational study on patients treated in the PICU of Hasan Sadikin General Hospital was conducted in November 2004-December 2004. The PELOD scoring system was applied to all subjects within the first 24 hours of PICU admission. The scoring system consists of physical and laboratory variables of 6 organs, namely neurological, cardiovascular, renal, respiratory, hematological, and hepatic systems. The sum of scores were analyzed by logistic regression method to calculate the probability of death. The subjects were monitored until they passed away or were discharged from PICU.

Results There were 32 subjects who met the inclusion criteria. The mean (SD) of PELOD scores in survivors was 13.5 (8.5) and in non survivors was 22.2 (10.1) $\left(Z_{M-W}=-2.507 ; P=0.012\right)$, while the mean of PELOD scores in survivors of PELOD scores validation study was 31.0, and in non survivors was 9.4. The increase of PELOD scores correlated with the increase in the probability of death $(P=0.038)$, and a linear regression chart showed a positive correlation $\left(R^{2}=0.93\right)$. PELOD scores at a $50 \%$ probability of death was 20 , while the mean PELOD scores validation study was 26 . Based on the probability of death of $\mathrm{P} \leq 0.5$, the death prediction and observed death had a sensitivity of $54.5 \%$ and a specificity of $80.9 \%$. Among patients with high PELOD scores $(\geq 20)$ and those with low PELOD scores $(<20)$, the number of patients who survived with extended length of stay in PICU, were not significantly different $(P=0.15)$.

Conclusions PELOD scoring system can be used to determine the patient's probability of death in PICU, but can not be used to predict the length of stay in PICU [Pediatr Indones 2006;46:1-6].
\end{abstract}

Keywords: PELOD score, prognosis, PICU he intensive care unit is an expensive
treatment facility where critical patients
with high mortality rates are treated. ${ }^{1}$
Estimation of disease severity and probability of death are important elements in determining the prognosis of patients in PICU. ${ }^{2}$ Such prognostic predictors need to be informed to the parents clearly to explain the objectives of treatment and to involve them in decision making process. ${ }^{2-5}$ Imperfections in informing prognosis will lead to inconvenience and uncomfortable situations for the patient's family. ${ }^{2}$

A more accurate prognostic assessment can lead to more appropriate monitoring, management, and family counseling. An objective and rational method to determine and estimate the severity of illness is by using a probability model which can predict mortality risks. For this reason, a scoring system is necessary to be developed. Currently, scoring systems have been

Presented at The $13^{\text {th }}$ National Child Health Congress, Bandung, Indonesia, July 4-7, 2005.

From the Department of Child Health, Medical School, Padjajaran University, Bandung, Indonesia.

Reprint requests to: Dewi Metta, MD, Department of Child Health, Medical School, Padjajaran University, Hasan Sadikin Hospital, Bandung, Indonesia. Tel.62-22-2034426; Email: dewi.metta@gmail.com. 
developed to estimate the probability of hospital mortality for intensive care unit (ICU) patients. ${ }^{6,7}$ These scoring systems, which can predict mortality or multiple organ dysfunction syndrome (MODS) outcomes, are available for both adults and children. Three MODS scores have been validated for adult patients, ${ }^{8,9}$ but only one MODS score for children, i.e, the pediatric logistic organ dysfunction (PELOD) scoring system. ${ }^{9}$

Recently, there is a tendency of increasing malpractice indictment toward physicians, especially those related to the deceased or permanently disabled patients. This may be due to inadequate information given by the physician on the severity of the disease and the alternative therapy comprehended by the families or parents. ${ }^{10}$ Considering that PICU patients usually have critical illness with high mortality risks, it is necessary to estimate the severity of the disease and the probability of death.

The objective of this study was to evaluate whether the PELOD scoring system can be utilized to determine the prognosis of patients treated in the PICU, Hasan Sadikin Hospital, Bandung.

\section{Methods}

A longitudinal observational study was conducted on patients treated in PICU at Hasan Sadikin Hospital, Bandung during November 2004-December 2004. The exclusion criteria were patients who, for any reason, did not undergo sufficient diagnostic laboratory tests in accordance with PELOD scoring procedures, and those who were discharged from PICU by request. The parents signed written informed consent prior to the study.

The PELOD scoring system consisted of physical and laboratory variables representing 6 organs, namely neurological, cardiovascular, renal, respiratory, hematological, and hepatic systems (Table 1). In all subjects, the PELOD scores were determined during the first 24 hours of admission in PICU. The scores

TABLE 1. PELOD SCORING SYSTEM

\begin{tabular}{|c|c|c|c|c|}
\hline \multirow{2}{*}{$\begin{array}{l}\text { Organ dysfunction and variable } \\
\text { Neurological }\end{array}$} & \multicolumn{4}{|c|}{ Scoring system } \\
\hline & 1 & 2 & 10 & 20 \\
\hline Glasgow coma score & $12-15$ & $7-11$ & $4-6$ & 3 \\
\hline Pupillary reactions & and & NA & $\begin{array}{l}\text { or } \\
\text { Both fixed }\end{array}$ & NA \\
\hline \multicolumn{5}{|l|}{$\begin{array}{l}\text { Cardiovascular } \\
\text { Heart rate (beats/min) }\end{array}$} \\
\hline $\begin{array}{l}<12 \text { years } \\
\geq 12 \text { years }\end{array}$ & $\begin{array}{l}\leq 195 \\
\leq 150\end{array}$ & $\begin{array}{l}\text { NA } \\
\text { NA }\end{array}$ & $\begin{array}{l}>195 \\
>150\end{array}$ & $\begin{array}{l}\text { NA } \\
\text { NA }\end{array}$ \\
\hline Systolic blood pressure by age $(\mathrm{mmHg})$ & and & & or & \\
\hline $\begin{array}{l}<1 \text { month } \\
1 \text { month }-1 \text { year } \\
1-12 \text { years } \\
\geq 12 \text { years }\end{array}$ & $\begin{array}{l}>65 \\
>75 \\
>85 \\
>95\end{array}$ & $\begin{array}{l}\text { NA } \\
\text { NA } \\
\text { NA } \\
\text { NA }\end{array}$ & $\begin{array}{l}35-65 \\
35-75 \\
45-85 \\
55-95\end{array}$ & $\begin{array}{l}<35 \\
<35 \\
<45 \\
<55\end{array}$ \\
\hline \multicolumn{5}{|l|}{$\begin{array}{l}\text { Renāl } \\
\text { Creatinine by age (umol/l) }\end{array}$} \\
\hline $\begin{array}{l}<7 \text { days } \\
7 \text { days }-1 \text { year } \\
1-12 \text { years } \\
\geq 12 \text { years } \\
\text { Respiratory }\end{array}$ & $\begin{array}{l}<140 \\
<55 \\
<100 \\
<140\end{array}$ & $\begin{array}{l}\text { NA } \\
\text { NA } \\
\text { NA } \\
\text { NA }\end{array}$ & $\begin{array}{l}\geq 140 \\
\geq 55 \\
\geq 100 \\
\geq 140\end{array}$ & $\begin{array}{l}\text { NA } \\
\text { NA } \\
\text { NA } \\
\text { NA }\end{array}$ \\
\hline $\mathrm{PaO}_{2}(\mathrm{kPa}) / \mathrm{FiO}_{2}$ ratio & $>9.3$ & NA & $\leq 9.3$ & NA \\
\hline $\begin{array}{l}\mathrm{PaCO}_{2}(\mathrm{kPa}) \\
\text { Mechanical ventilation } \\
\text { Hematological }\end{array}$ & $\begin{array}{c}\text { and } \\
\leq 11.7 \\
\text { No } \\
\text { ventilation }\end{array}$ & $\begin{array}{c}N A \\
\text { Ventilation }\end{array}$ & $\begin{array}{c}\text { or } \\
>11.7 \\
\text { NA }\end{array}$ & $\begin{array}{l}\text { NA } \\
\text { NA }\end{array}$ \\
\hline White blood cell count (x 109/l) & $\geq 4.5$ & $1.5-4.4$ & $<1.5$ & NA \\
\hline $\begin{array}{l}\text { Platelets (x 109/l) } \\
\text { Hepatic }\end{array}$ & $\begin{array}{l}\text { and } \\
\geq 35\end{array}$ & $\begin{array}{c}\text { or } \\
<35\end{array}$ & NA & NA \\
\hline Aspartate transaminase (IU/I) & $<950$ & $>950$ & NA & NA \\
\hline Prothrombin time (or INR) & $\begin{array}{c}\text { and } \\
>60 \\
(<1.40)\end{array}$ & $\begin{array}{c}\text { or } \\
\leq 60 \\
(\geq 1.40)\end{array}$ & NA & NA \\
\hline
\end{tabular}

2・ Paediatrica Indonesiana, Vol. 46, No. 1-2 • January - February 2006 
for each variable accounted was the highest points. For example, a boy with a heart rate of 200 beats/ minute (10 points), his systolic blood pressure is 30 $\mathrm{mmHg}$ (20 points), his score for the cardiovascular variable was 20 points. The sum of the 6 score variables was then defined as the PELOD score, by which the probability of a patient's death was calculated by a logistic regression method. Patients were then monitored until they were discharged from PICU or deceased.

Ethical approval for this study was obtained from the Medical Ethics Committee at Medical School, Padjajaran University, Hasan Sadikin Hospital. Data were analysed by SPSS version 10.0. To assess the correlation between PELOD scores and mortality, we used Z Mann-Whitney test and linear regression. To find the correlation between PELOD score with probability of death, we used logistic regression. To assess correlation and accurateness between the probability of death accounted based on PELOD scores and observed mortality which occured, we used linear regression analysis and sensitivity and specificity tests. For correlation between mortality and the length of stay in PICU, we used survival analysis with Kaplan-Meier method.

\section{Results}

There were 32 subjects (20 males and 12 females) recruited in this study, aged between 2-156 months (mean 40.3). Eleven out of them died. The lengths of stay in PICU were between 10-465 hours (mean 148.6). Three patients were surgical cases. Twenty out of 32 patients were in mechanical ventilators.

The observed PELOD scores ranged between 142 (mean of 12.5 and variance of 9.8). Distribution of PELOD scores among survivors and non-survivors are shown on Table 2 .

The mean (SD) of PELOD scores among survivors was $13.5(8.5)$, while this value among non-survivors was 22.2(10.1). By Z Mann-Whitney test, it was found that PELOD scores of non-survivors was significantly higher than those of survivors $\left(\mathrm{Z}_{\mathrm{M}-\mathrm{W}}=-2.507\right.$ and $\mathrm{P}=0.012$ ).

Correlation between PELOD scores and outcome described by mortality proportion, which occurred in PICU can be seen in Figure 1.

Based on statistical calculation by logistic re- gression analysis with death as a dependent variable and PELOD scores as an independent variable, we found that there was a constancy of $\left(b_{0}\right)=-2.038$ and logistic regression coefficient of PELOD scores of $\left(b_{1}\right)=0.104$; then an equation was built as follows $Y=-2.038+0.104 \times$ PELOD scores, $Y$ as probability of death.

From the above equation, probability of death (P) of various PELOD scores could be calculated by applying formula:

$$
\mathrm{P}=\frac{1}{1+\exp ^{-(a+b x)}}
$$

In turn, a chart shown in Figure 2 could be drawn.

Figure 2 shows the significant correlation be-

Table 2. Distribution of PElod scores among SURVIVORS AND NON-SURVIVORS

\begin{tabular}{cccc}
\hline PELOD scores & Frequency & Survivors & $\begin{array}{c}\text { Non- } \\
\text { Survivors }\end{array}$ \\
\hline 1 & 3 & 3 & - \\
2 & 7 & 6 & 1 \\
10 & 1 & 1 & - \\
11 & 2 & 2 & - \\
12 & 6 & 3 & 3 \\
13 & 2 & 1 & 1 \\
14 & 1 & 1 & - \\
20 & 2 & 2 & - \\
21 & 5 & - & 5 \\
22 & 1 & 1 & - \\
31 & 1 & 1 & 1 \\
42 & 1 & - & 11 \\
\hline
\end{tabular}

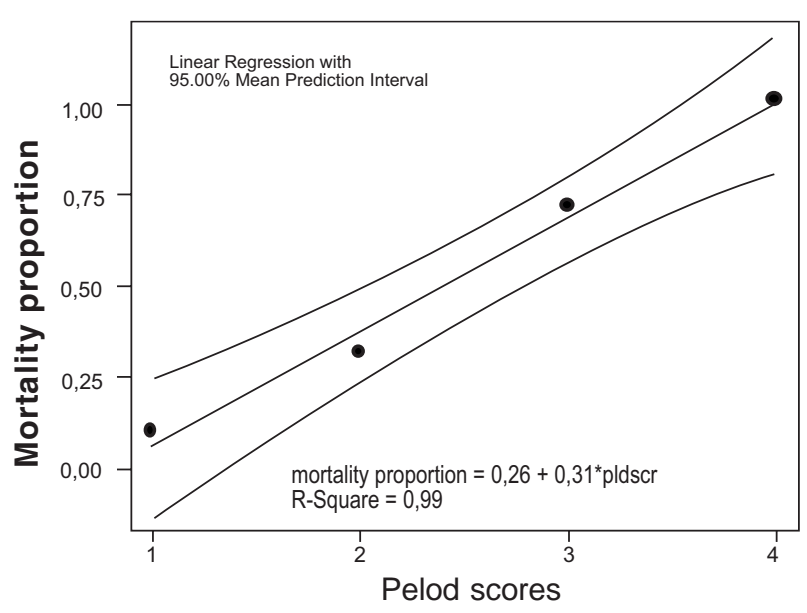

Figure 1. Correlation between PELOD scores and MORTALITY 
tween PELOD scores and probability of death $(\mathrm{P}=0.038)$. The PELOD scores of 20 correlated with a $50 \%$ probability of death.
The higher the PELOD scores, the higher the mortality proportion would be. This was described by the positive correlation value on the linear regression

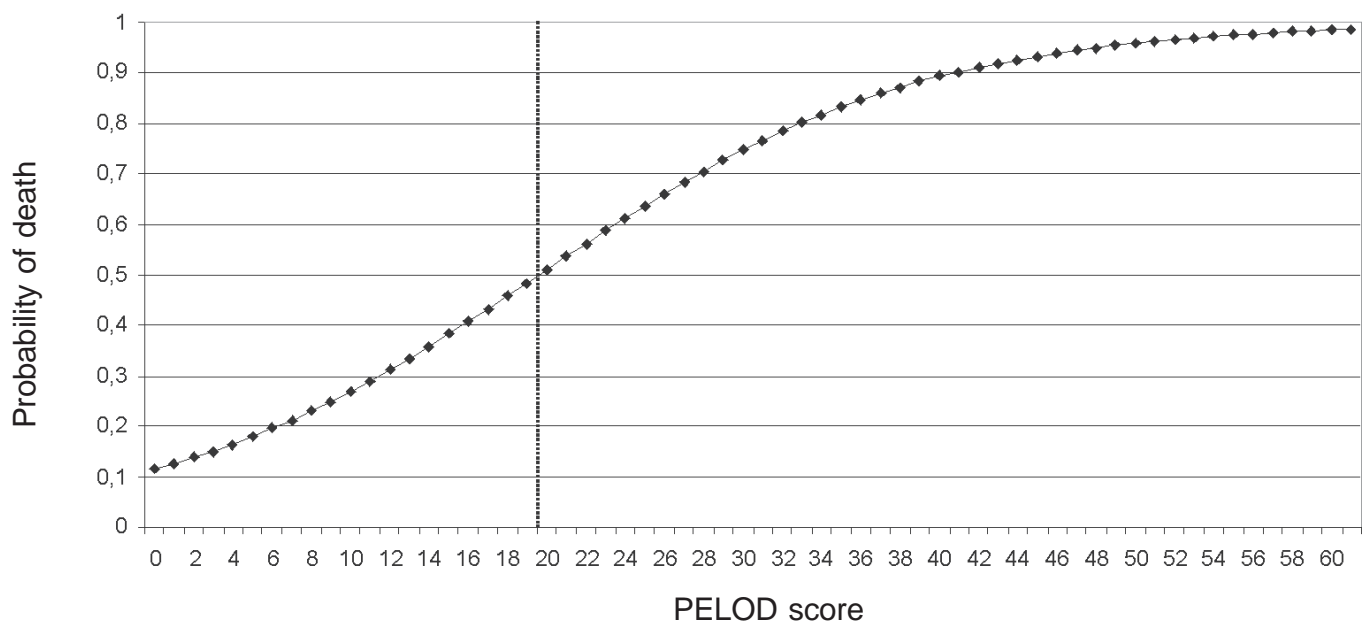

Figure 2. Correlation between PELOD scores and probability of Death

When the probability of death by equation was related with the observed mortality which occurred in PICU, the results are seen on Table 3 and Figure 3 would be obtained.

To obtain preciseness between the probability of death and the occurrence of mortality, sensitivity and specificity test was taken, positive predictive value (PPV), negative predictive value (NPV), and likelihood ratio for a positive test result $\left(\mathrm{LR}^{+}\right)$had a different probability of death point of intersections, as seen on Table 4 .

Figure 4 shows that at a high PELOD scores $(\geq 20)$, the more extended the length of stay in PICU, the less the number of survivors were. Yet, the correlation between PELOD scores and length of stay in PICU was insignificant $(\mathrm{P}=0.15)$.

\section{Discussion}

From this study, it was obtained that the mean of PELOD scores was 12.4. Mean (SD) of PELOD scores of survivors was $13.5(8.5)$, which was significantly higher than those of non-survivors, 22.2(10.1) $\left(\mathrm{Z}_{\mathrm{M}-\mathrm{W}}=-2.507 ; \mathrm{P}=0.012\right)$. The validation study of PELOD scores found that the mean PELOD scores of non-survivors was 31.0 and those of survivors was $9.4(\mathrm{P}=0.0001) .{ }^{9}$
Table 3. Distribution of PiCU outcomes based on PROBABILITY OF DEATH

\begin{tabular}{cccc}
\hline Probability of death & $N$ & Survivors & Non-Survivors \\
\hline $0-0.20$ & 10 & 9 & 1 \\
$0.21-0.40$ & 12 & 8 & 4 \\
$0.41-0.60$ & 9 & 4 & 5 \\
$0.61-0.80$ & 0 & 0 & 0 \\
$0.81-1.00$ & 1 & 0 & 1 \\
\hline & 32 & 21 & 11 \\
\hline
\end{tabular}

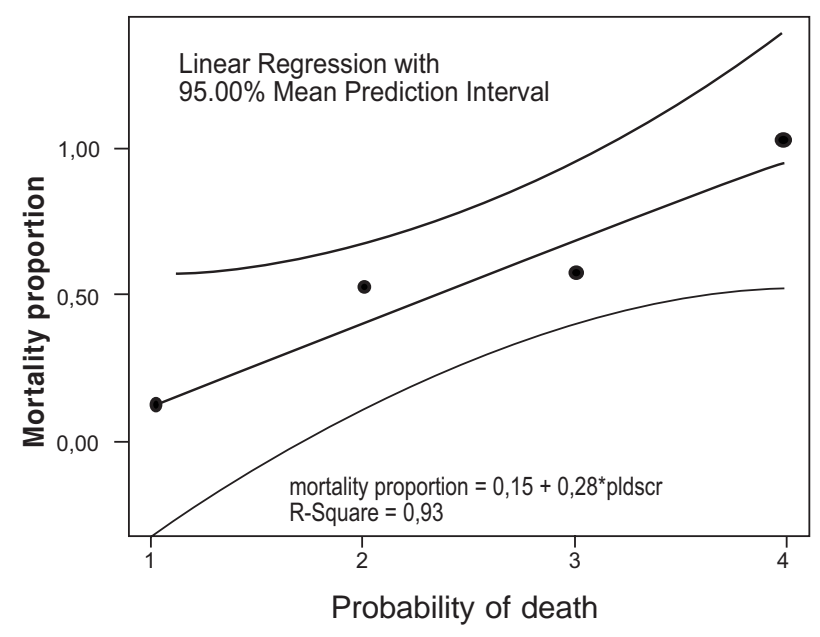

Figure 3. Correlation betWeEN PROBability OF DEATH AND MORTALITY PROPORTION OCCURRED IN PICU 
chart with $\mathrm{R}^{2}=0.99$. By statistical calculation of logistic regression, the equation of $Y=-2.038+(0.104 x$ PELOD scores) was obtained with $Y$ as probability of death. Based on the equation, PELOD scores at a 50\% probability of death was 20 . It was lower than the rate obtained by Leteurtre et al, ${ }^{9}$ which was 26 .

The occurrence of mortality proportion was in accordance with the probability of death calculated based on PELOD scores. It was shown by positive correlation with $\mathrm{R}^{2}=0.93$ of linear regression chart. cular emergencies ranked at first and second place. The number of mechanically ventilated patients were 21 out of 32. This differs from Leteurtre et $a l,{ }^{9}$ where neurological and cardiovascular emergencies ranked at the first and second place, with $51 \%$ of patients using mechanical ventilation devices.

Nearly all patients treated in PICU in this study had medical emergency; only 3 of 32 patients were surgical patients. In Leteurtre et al,,$^{9}$ as many as $49 \%$ of patients were surgical patients.

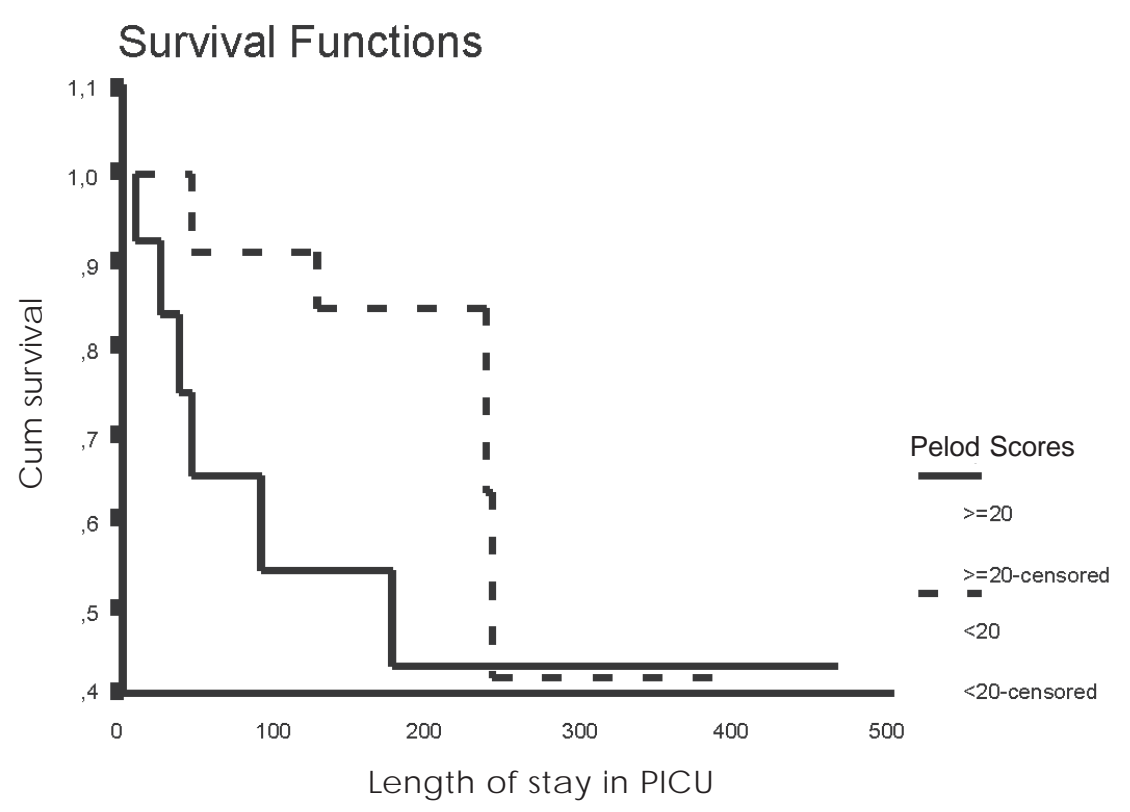

Figure 4. Correlation betWeen survivors With high and LoW PELOD scores WITH LENGTH OF STAY IN PICU

The different results of this study might be caused by the different population of patients in various PICU and the utilization frequency of facilities. ${ }^{11}$

The mean age of patients treated in PICU in Leteurtre et al's study was 24 months (range 5-90 months), ${ }^{9}$ which was younger than that found in our study [40 months (ranged 2 to 156 months)].

PELOD scores of patients in this study (mean $=12.5$, range $1-42$ ) was slightly higher than that of Leteurtre et $a l^{9}$ (mean $=10.8$, range $=0-71$ ). Patients with higher PELOD scores posed higher mortality risk.

In this study, the respiratory and cardiovas-
PICU at Hasan Sadikin Hospital consisted of 4 beds equipped with mechanical ventilation and monitoring devices. PICU facilities at validation test of PELOD scores, was not taken into account, therefore the difference cannot be determined. Yet, in general, PICU facilities in developed countries are better equipped than those of developing countries. They are better in technology and human resources as well. The differences are found in the skills of the physicians and nurses; patient:nurse ratio affects the quality of patient treatment in PICU. ${ }^{12}$

To obtain the smallest result of false positive, high specificity is required. Hence, it can be assumed that, 
patients with high PELOD scores are those who are severely ill with a high probability of death. Table 4 shows that the sensitivity and specificity rates are different at different points of probability of death points. The highest specificity was found at mortality point of intersection with probability of death of $\leq 50 \%$ and $\leq 40 \%$. Given that the likelihood ratio at probability of death of $\mathrm{P} \leq 0.5$ as high as 2.4 , and at probability of death of $\mathrm{P} \leq 0.3$ was 2.1 , it can be assumed that probability of death of $\mathrm{P} \leq 0.5$ and $\mathrm{P} \leq 0.3$ give a moderate diagnostic test.

Table 4. Preciseness between probability of death and THE OCCURRED RESULT IN PICU

\begin{tabular}{lccccc}
\hline $\begin{array}{c}\text { Probability of } \\
\text { death }\end{array}$ & $\begin{array}{c}\text { Sensitivity } \\
(\%)\end{array}$ & $\begin{array}{c}\text { Specificity } \\
(\%)\end{array}$ & $\begin{array}{c}\text { PPV } \\
(\%)\end{array}$ & $\begin{array}{c}\text { NPV } \\
(\%)\end{array}$ & LR $^{+}$ \\
\hline $\mathrm{P} \leq 0,5$ & 54.5 & 80.9 & 60.0 & 77.3 & 2.4 \\
$\mathrm{P} \leq 0,4$ & 54.5 & 80.9 & 60.0 & 77.3 & 2.4 \\
$\mathrm{P} \leq 0,3$ & 90.9 & 57.1 & 52.6 & 92.3 & 2.1 \\
$\mathrm{P} \leq 0,2$ & 90.9 & 42.8 & 45.5 & 90.0 & 1.6 \\
\hline
\end{tabular}

Notes: PPV = positive predictive value $\mathrm{NPV}=$ negative predictive value $\mathrm{LR}^{+}=$likelihood ratio for a positive test result

The limitation to this study was that PELOD scores usage did not consider other aspects that might affect mortality, such as nutritional status, immunodeficiency, post surgery, length of illness, and previous treatment.

In this study it was found that nutritional status of 6 out of 11 non-survivors and 3 out of 21 survivors, were categorized as protein energy malnutrition grades II and III. Five out of 6 non-survivors with poor nutritional status posed less than $50 \%$ probability of death. It seems to be important to take nutritional status into account.

Among patients with high PELOD scores (>20), the numbers of survivors left were lessen by the extended length of stay in PICU. Yet, it was not significantly different $(\mathrm{P}=0.15)$, between survivors at high and low PELOD scores, related to the length of stay in PICU. It was because patients with high PELOD scores died after a short time period of treatment in PICU or survived but were treated for quite long in PICU.

As a conclusion, PELOD scoring system is reliable to determine the probability of death in PICU, but other aspects, such as nutritional status, immunodeficiency, post surgery, length of illness, and previous treatment that might affect mortality should be well considered. PELOD scoring system was not used to estimate the length of stay in PICU. Further studies on the use of PELOD scoring system on patients prior to admission in PICU will be required to assist physicians in delivering thorough information to patients' family before starting PICU treatment.

\section{References}

1. Gunning K, Rowan K. Outcome data and scoring system. Br Med J 1999;319:241-4.

2. Marcin JP, Pollack MM, Patel KM, Sprague BM, Ruttimann UE. Prognostication and certainty in the paediatric intensive care unit. Pediatrics 1999;104:868-73.

3. Fiser DH. Assessing the outcome of pediatric intensive care. J Pediatr 1992;121:68-74.

4. Tan GH, Tan TH, Goh DYT, Yap HK. Risk factors for predicting mortality in a paediatric intensive care unit. Ann Acad Med Singapore 1998;27:813-8.

5. Rocker G, Cook D, Sjokvist P, Weaver B, Finfer S, McDonald E, et al. Clinician prediction of intensive care unit mortality. Crit Care Med 2004;32:1149-54.

6. Seneff MG, Zimmerman JE, Knaus WA. Severity of illness indices and outcome prediction: Development and evaluation. In: Ayres SM, Grenvick A, Holbrook PR, Shoemaker WC, editors. Textbook of critical care; 3rd ed. Philadelphia: WB Saunders Company; 1995. p. 1777-88.

7. Lemeshow S, Le Gall JR. Modelling the severity of illness of ICU patients. A systems update. JAMA 1994; 272:1049-55.

8. Petilla V, Petilla M, Sarna S, Voutilainen P, Takkunen O. Comparison of multiple organ dysfunction scores in the predicting of hospital mortality in the critically ill. Crit Care Med 2002;30:1913-4.

9. Leteurtre S, Martinot A, Duhamel A, Proulx F, Grandbastien B, Cotting J, et al. Validation of the paediatric logistic organ dysfunction (PELOD) score: Prospective, observational, multicentre study. Lancet 2003;362:192-7.

10. Safitri H. Sengketa medik, alternatif penyelesaian perselisihan antara dokter dengan pasien. Jakarta: Diadit Media; 2005. p. 57-82.

11. Pollack MM. Outcome analysis. In: Holbrook PR, editors. Textbook of pediatric critical care. Philadelphia: WB Saunders Company; 1993. p. 1151-9.

12. Goh AYT, Lum LCS, Chan PWK. Paediatric intensive care in Kuala Lumpur, Malaysia: A developing subspecialty. J Trop Pediatr 1999;45:362-4. 